\title{
STRATIGRAPHICAL STUDIES ON LAKE IIDESJÄRVI SEDIMENTS PART I: ENVIRONMENTAL CHANGES AND PALAEOLIMNOLOGICAL DEVELOPMENT
}

\author{
PENTTI ALHONEN
}

\begin{abstract}
ALHONEN, P. 1981: Stratigraphical studies on Lake Iidesjärvi sediments. Part 1. Environmental changes and palaeolimnological development. Bull. Geol. Soc. Finland 53-2, 97-107.

Palaeolimnological results for the small eutrophicated lake Iidesjärvi in the town of Tampere (S. Finland) show that it has been limnologically more or less productive since its isolation from the Ancylus Lake of the Baltic Sea. Successive radiocarbon datings from the lithostratigraphy have shown that the annual sedimentation rate for an eutrophic lake was $0.755 \mathrm{~mm} / \mathrm{yr}$. Long-term changes reflected in the pollen stratigraphy represent known phases of regional vegetational history in the catchment area of Lake Iidesjärvi. In addition, signs of early land use can be detected in the pollen data. Increased human activity, viz. settlement and the growth of industry in Tampere, have caused sulphide-banded clay-gyttja to form in the topmost lithostratigraphy, thereby indicating oxygen deficits in the hypolimnion of Iidesjärvi during thermal stratification. The cultural eutrophication of the lake has probably been taking place since the beginning of this century, especially since the $1950 \mathrm{~s}$.
\end{abstract}

Pentti Alhonen, Department of Geology, Division of Geology and Palaeontology, University of Helsinki, Snellmaninkatu 5, SF-00170 Helsinki 17, Finland.

\section{Introduction}

Environmental changes in and the limnological history of a lake can be traced in the stratigraphy of its bottom sediments. This is especially important and useful in eutrophicated and polluted lakes, because the developmental stages of cultural eutrophication as a long-term phenomenon can be demonstrated on a litho-, bio- and chemostratigraphical basis (see Alhonen 1979).

The main purpose of this paper is to obtain palaeolimnological information on the effects of the industrial town of Tampere on the small heavily eutrophicated Lake Iidesjärvi and to compare this with its natural development before the pollution stage. In the first part of this study special attention is paid to radiocarbon chronology for the knowledge it gives us of sedimentation rates and vegetational history in the surroundings of Lake Iidesjärvi. Changes in diatom stratigraphy have been used to show the isolation of the lake from the Baltic Sea and the limnological development of its lake type.

It should be stressed that the natural economy of a lake depends greatly on the nutrient content of the geological deposits in its environment. Therefore they must always be considered as an important environmental factor providing a more accurate interpretation of palaeolimnological evidence. 


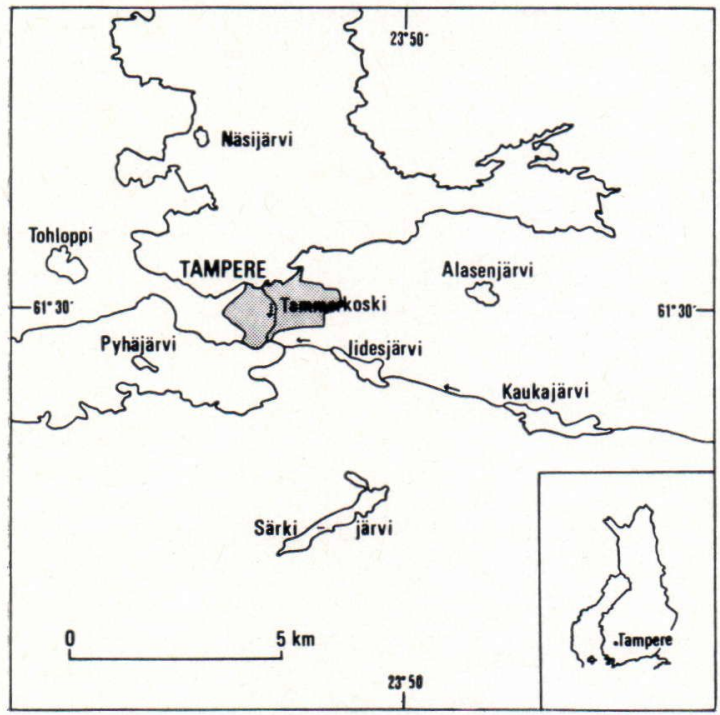

Fig. 1. Map showing the location of Lake Iidesjärvi.

\section{The lake and its environment}

\section{Geology}

The Precambrian environment of Lake Iidesjärvi $\left(61^{\circ} 29^{\prime} \mathrm{N}\right.$ and $\left.23^{\circ} 50^{\prime} \mathrm{E}\right)$ in the region of the city of Tampere is characterized mainly by mica gneiss. Basic tuffite and amphibolite occur on its southern shore and peridotite is also found nearby (Matisto 1977).

Clay and silt predominate as superficial deposits around the lake, but peat deposits also occur at its eastern end (Virkkala 1962). The geological development of the area during the Holocene Epoch was associated with the history of the Baltic Sea immediately after deglaciation. Its oldest stage in the Tampere region was the Yoldia phase, the highest level of which varies between 160 and $175 \mathrm{~m}$. The altitude corresponding to the highest limit of the Ancylus Lake is nowadays $100-110 \mathrm{~m}$ above sea level. The marine Litorina stage did not reach the immediate environment of Lake Iidesjärvi (Virkkala 1962).
The most important palaeohydrological event in the Tampere region has no doubt been the development of Lake Näsijärvi and its influence on the history of Lake Pyhäjärvi and possibly also on Lake Iidesjärvi. According to the morphological study by Tolvanen (1924), Lake Näsijärvi discharged after isolation from the Ancylus Lake into the Gulf of Bothnia through the river Lapuanjoki. As a result of land tilting, transgression took place throughout the whole basin. Finally, the rising waters broke a new outlet channel through the Tampere (Pyynikki) esker at the southern end of the lake, thereby producing the Tammerkoski rapids. According to Virkkala (1949 and 1962; see also Saarnisto 1971), this happened in the third millenium B.C., but no reliable radiocarbon datings of the change of channel exist. As Lake Näsijärvi discharged southwards through Tammerkoski, a transgression of about two metres took place in Lake Pyhäjärvi (Virkkala 1949). This rise in the water level may have been felt in Lake Iidesjärvi as well.

\section{Limnology}

Lake Iidesjärvi (altitude $77.1 \mathrm{~m}$ ) in the town of Tampere (Fig. 1), is a morphologically longish basin lying in a westeasterly direction. It is $2000 \mathrm{~m}$ long and $800 \mathrm{~m}$ wide at its widest. The lake is part of the water course of the river Kokemäenjoki. It receives additional waters from Lake Kaukajärvi through Vuohenoja and it flows through Viinikanoja into Lake Pyhäjärvi. Settlements and cultivated fields abound in the catchment area of Lake Iidesjärvi. The lake covers 60 ha; its greatest depth is $4 \mathrm{~m}$, the average depth being about $1.2 \mathrm{~m}$.

The Secchi disk transparency in Lake Iidesjärvi is low, varying according to different observations from 0.2 to $0.5 \mathrm{~m}$. The colour of the water is brown (about $100 \mathrm{Pt} \mathrm{mg/l}$ ) 


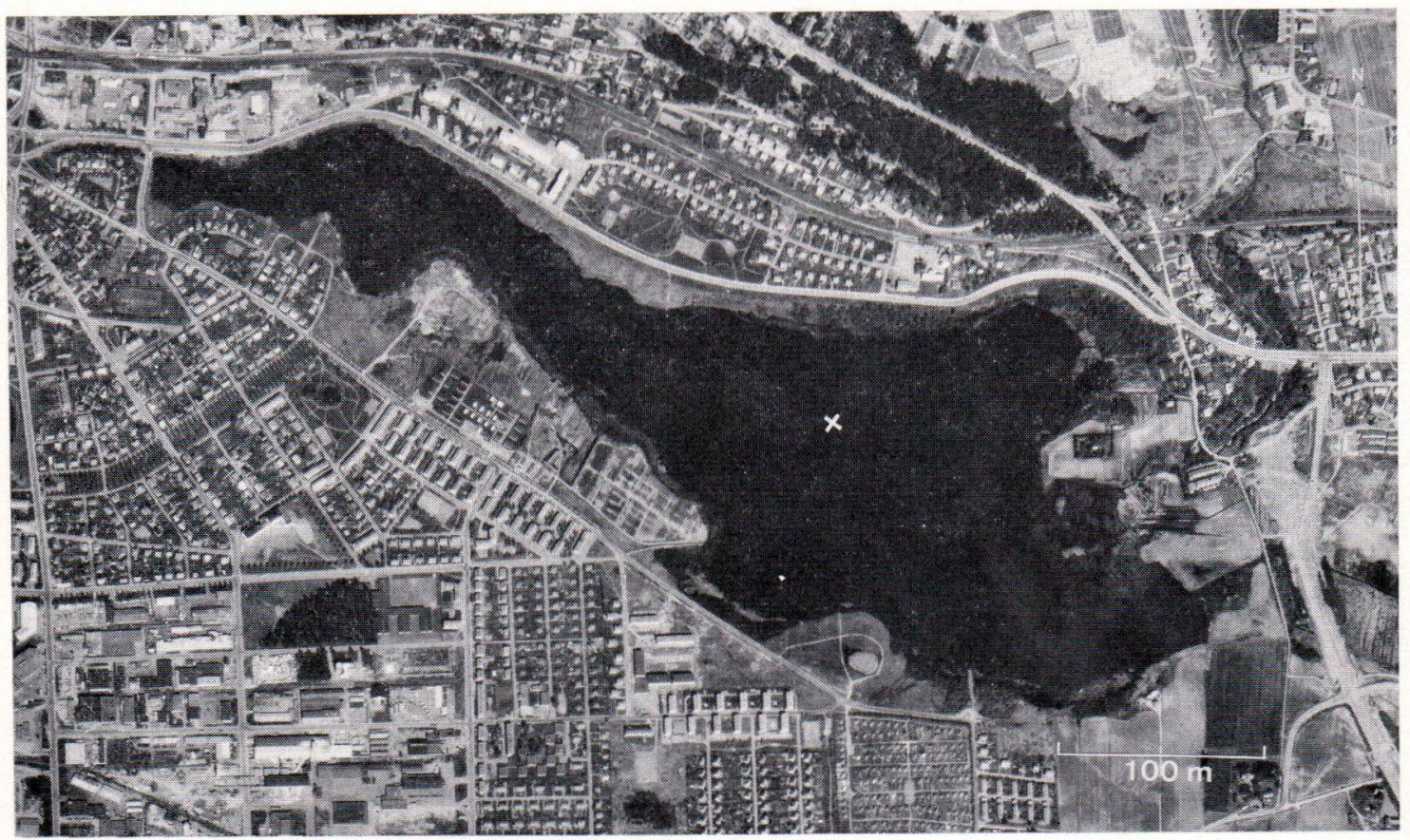

Fig. 2. Air photograph 77156:93 (212311) of Lake Iidesjärvi showing the sampling site (published with permission of the General Survey Office).

and, especially in summer, the water is muddy because of high primary production; $\mathrm{pH}$ values are therefore also high. In the early 1970's the $\mathrm{pH}$ was near 10 !, and the amounts of phosphorus and nitrogen conspicuously higher than in Finnish lakes normally. For example during the winter of 1972, the phosphorus content was $1.4 \mathrm{mg} / 1$, nitrogen $1.3-1.6 \mathrm{mg} / 1$ and chloride $28 \mathrm{mg} / 1$. Conductivity values have varied between 130 and $160 \mu \mathrm{S}$ in the summer and between 250 and $280 \mu \mathrm{S}$ in the winter (see Toivonen and Ranta 1976).

Lake Iidesjärvi is a typical example of cultural eutrophication, connected herewith the settlement and industrial history of the town of Tampere. Oxygen deficiencies are common because of the high nutrient level resulting from sewage. This is reflected in the composition of the plankton (Järnefelt 1956; see also Ilmavirta 1980) and of the macrophyte flora (Toivonen and Ranta 1976; see also Toivonen 1980). The predominant species are Phragmites australis, Equisetum fluviatile, Schoenoplectus lacustris and Nuphar lutea, which form extensive stands in the lake (Toivonen and Ranta 1976).

\section{Field and laboratory methods}

\section{Coring}

The samples for radiocarbon dating and stratigraphical analyses were taken in the winter of 1979 from the deepest point of the lake, where the water reaches $4 \mathrm{~m}$ with a Livingstone piston sampler fitted with $2 \mathrm{~m}$ long core tubes whose internal diameter was $5.4 \mathrm{~cm}$ (see Fig. 2). The main core in three successive tubes intersecting the total thickness of lake gyttja down to the clay bottom 
was transported directly to the laboratory. The samples were taken from the core tubes by sawing them open lengthwise. Immediately after this procedure visual observations were made on the bottom sediments.

\section{Pollen analysis}

Pollen slides were made in the usual way (see e.g. Alhonen 1967, pp. 5-6), and 150200 tree pollen grains were counted from each preparation. In the diagram the pollen were grouped into trees, shrubs, dwarf shrubs, herbs and cryptogams. The pollen analysis is not intended to show early land use in detail, but only to give a general impression of the vegetational succession in the environment of the lake.

\section{Diatoms}

Organic matter was removed from the diatom samples by keeping the material in an oven in a $30 \%$ solution of hydrogen peroxide for 24 hours at $50^{\circ} \mathrm{C}$. Mineral matter was then eliminated by repeated suspending and decanting. Slides were prepared using Caedax (index of refraction 1.54) as a mounting medium. From 200 to 250 diatom taxa were identified and used as a basic sum. The mutual proportions of the diatom species selected are given as percentages in the diagram (Fig. 6).

\section{The results}

\section{Lithostratigraphy}

The lithostratigraphy of the main core is as follows (Fig. 3):

0- $42 \mathrm{~cm}$ Pale grey clay-gyttja with sulphide bands and spots

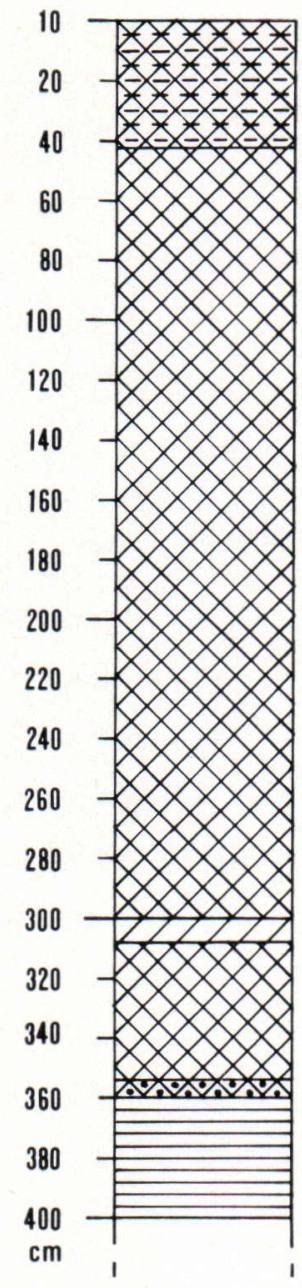

PALE GREY CLAY-GYTTJA WITH SULPHIDE BANDS AND SPOTS

BROWN, COMPACT

FINE DETRITUS GYTTJA

PALE GREY GYTTJA LAYER

DARK BROWN, COMPACT

FINE DETRITUS GYTTJA

GREY CLAY-GYTTJA

BANDED SULPHIDE CLAY

Fig. 3. Lithostratigraphy of the investigated profile.

$42-300 \mathrm{~cm}$ Brown, compact fine detritus gyttja

$300-308 \mathrm{~cm}$ Pale grey gyttja layer

308-357 cm Dark brown, compact fine detritus gyttja

$357-360 \mathrm{~cm}$ Grey clay-gyttja

360 - Banded sulphide clay; thickness not measured

The sediment symbols given in the lithostratigraphical column were also used in other figures. 


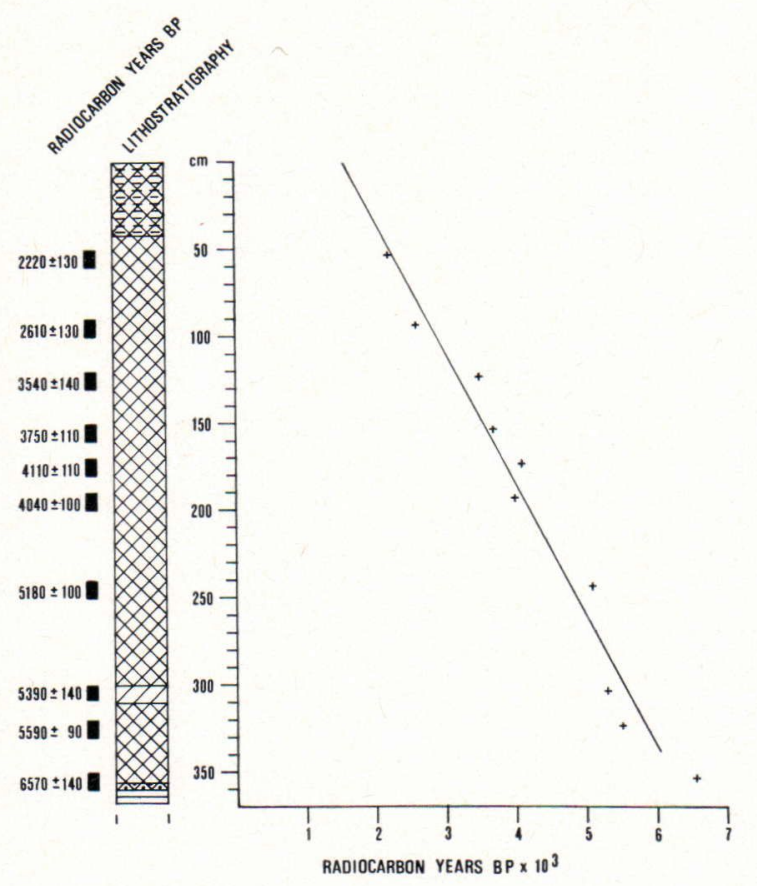

Fig. 4. Plot of the radiocarbon dates against sediment depth (lithostratigraphical symbols shown in Fig. 3).

\section{Radiocarbon dates}

The ten 8 to 10 -cm-long segments of sediment samples obtained from the main core were dated at the Radiocarbon Dating Laboratory, University of Helsinki. The results are given in Table 1 . They are conventional uncorrected radiocarbon years before A.D. 1950 and are based on a ${ }^{14} \mathrm{C}$ half life of $5568 \pm 30$ years. These age determinations were used to draw a regression line (Fig. 4), which gave an overall sedimentation rate of $0.755 \mathrm{~mm} /$ year. It is not possible on the basis of the data available to draw detailed conclusions on the possible changes in the deposition rate of the sediments in Lake Iidesjärvi.

\section{Pollen stratigraphy}

The pollen stratigraphy (Fig. 5) of the main core is divided according to the Flandrian
Table 1. Radiocarbon dates from an Iidesjärvi core based on a ${ }^{14} \mathrm{C}$ half life of 5568 years.

\begin{tabular}{lrr}
\hline $\begin{array}{l}\text { Reference } \\
\text { number }\end{array}$ & $\begin{array}{c}\text { Depth } \\
\mathrm{cm}\end{array}$ & $\begin{array}{c}\text { Radiocarbon } \\
\text { years B.P. }\end{array}$ \\
\hline Hel-1370 & $50-60$ & $2220 \pm 130$ \\
Hel-1371 & $90-100$ & $2610 \pm 130$ \\
Hel-1372 & $120-130$ & $3540 \pm 140$ \\
Hel-1373 & $150-160$ & $3750 \pm 110$ \\
Hel-1374 & $170-180$ & $4110 \pm 110$ \\
Hel-1375 & $190-200$ & $4040 \pm 110$ \\
Hel-1376 & $240-250$ & $5180 \pm 100$ \\
Hel-1377 & $300-308$ & $5390 \pm 140$ \\
Hel-1378 & $320-330$ & $5590 \pm 90$ \\
Hel-1379 & $350-360$ & $6570 \pm 140$ \\
\hline
\end{tabular}

(Holocene) regional (S.W. Finland) pollen assemblage zones (see e.g. Donner 1971, pp. 283 -284), of which three can be recognized in the diagram. At the base of the pollen stratigraphy the upper part of the Pine Zone is visible in the banded sulphide clay. Its boundary with the Birch-alder-hazel-elm Zone occurs near the lithostratigraphical transition from sulphide clay to clay-gyttja. The upper limit of this zone can be seen in the pollen diagram at a depth of $100 \mathrm{~cm}$ in fine detritus gyttja, where the uppermost Spruce-pine Zone begins. The beginning of the continuous curve for Tilia $\left(\mathrm{T}^{\circ}\right)$ in the lower part of the Birch-alder-hazel-elm Zone and the rational limit for Picea $\left(\mathrm{P}^{\circ}\right)$ in its upper part can be used as local chronostratigraphical levels.

The marked herb occurrence in the Sprucepine Zone indicates human activity in the environment of the lake. Incipient primitive land use for agricultural purposes is revealed as the appearance of cereal pollen together with a general relative increase of NAP in the uppermost part of the Spruce-pine Zone.

With the aid of the radiocarbon dates obtained from the samples of the core studied, the pollen assemblage zones can also be used as the Flandrian Chronozones (see Mangerud et al. 1974). Thus the upper part of the pine zone can be correlated with the Late Boreal 


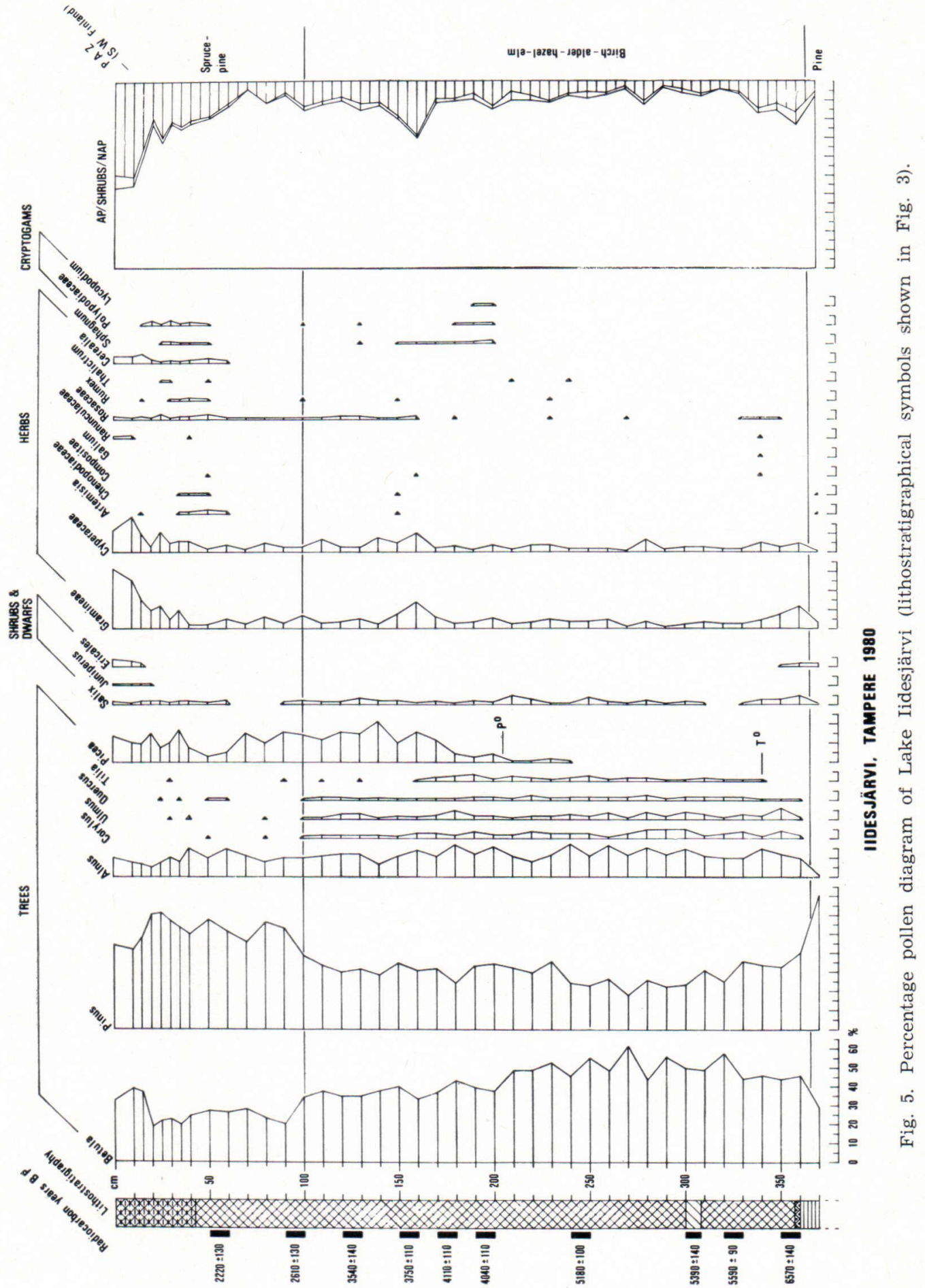


Chronozone. The boundary between it and the Atlantic Chronozone is defined at 8000 radiocarbon years B.P. The oldest date from the lithostratigraphy of Lake Iidesjärvi is, however, $6570 \pm 140$ B.P., which corresponds to the Middle Atlantic Chronozone.

The Atlantic/Subboreal Chronozone boundary is defined at 5000 radiocarbon years B.P., and the boundary between the Subboreal and Subatlantic Choronozones at 2500 B. P. (Mangerud et al. 1974, p. 122). This limit corresponds to the Birch-alder-hazel-elm/Sprucepine boundary and shows a ${ }^{14} \mathrm{C}$ date of 2610 \pm 130 B.P. in the pollen diagram of Fig. 5 (see also Donner 1971 and 1972).

\section{Diatom stratigraphy}

The diatom stratigraphy of Lake Iidesjärvi showing the dominant species only is given in diagrammatic form in Fig. 6. It has been divided into zones on the basis of the changes in the diatom assemblages. In the basal part of the lithostratigraphy the flora is characterized by taxa such as Melosira islandica ssp. helvetica, M. arenaria, Campylodiscus noricus, C. noricus v. hibernica, Cymatopleura elliptica, Diploneis mauleri, Gyrosigma acuminatum and $G$. attenuatum. These species belong to the diatom flora typical of Ancylus Lake (= Diatom Zone A) sediments. In the transition from banded sulphide clay to clay-gyttja there is a distinct change in diatoms corresponding to the Diatom Zone boundary A/I 1. This limit locates the isolation stage of Lake Iidesjärvi from the Ancylus Lake. Here, the typical clear-water forms of the Diatom Zone A disappear and are replaced by ordinary fresh-water taxa such as Melosira granulata, M. ambigua and $M$. italica, which all predominate in the Diatom Zone I 1.

In the uppermost part of the diatom strati- graphy two zones can be distinguished. The boundary between I 1 and I 2 is characterized by a clear decline in the curves of Melosira ambigua and $M$. italica. At the same time the curve of Surirella robusta rises and Melosira granulata v. angustissima appears in the diatom stratigraphy. In the Diatom Zone I 3 Melosira ambigua disappears and $M$. granulata v. angustissima becomes dominant. Some taxa similar to the Diatom Zone A reappear, but they are most probably of secondary origin in this part of the lithostratigraphy.

The diagram in Fig. 6 shows further that throughout the whole history of Iidesjärvi the three dominant diatoms have almost always been Melosira granulata, $M$. ambigua and $M$. italica. Both $M$. granulata and $M$. ambigua are typical of and common in the plankton of eutrophic lakes (e.g. Jørgensen 1948, Mö1der and Tynni 1967, Kilham and Kilham 1975, Bradbury 1975, 1978, p. 32 and Tolonen et al. 1976). Especially Melosira granulata is the most characteristic diatom in eutrophic waters in Europe (Hustedt 1945; see also Hutchinson 1967, p. 396). In contrast, according to Mölder and Tynni (op. cit., p. 208) Melosira italica predominates in oligotrophic and dystrophic lakes, although the observations of Järnefelt (1952) show that it can be eutrophic. The recent pollution stage of Iidesjärvi is successively characterized by Melosira granulata, Surirella robusta, Gyrosigma acuminatum and Melosira granulata v. angustissima.

The occurrence of Gyrosigma acuminatum $(20 \%)$ is interesting. It is the most common Gyrosigma species in Finland. Being an alkaliphilous form (Tynni 1978, p. 5) it together with the other diatom assemblages probably indicates the recent development of pollution in Iidesjärvi. Surirella robusta is ecologically pH indifferent (Tynni 1980, p. 26). 


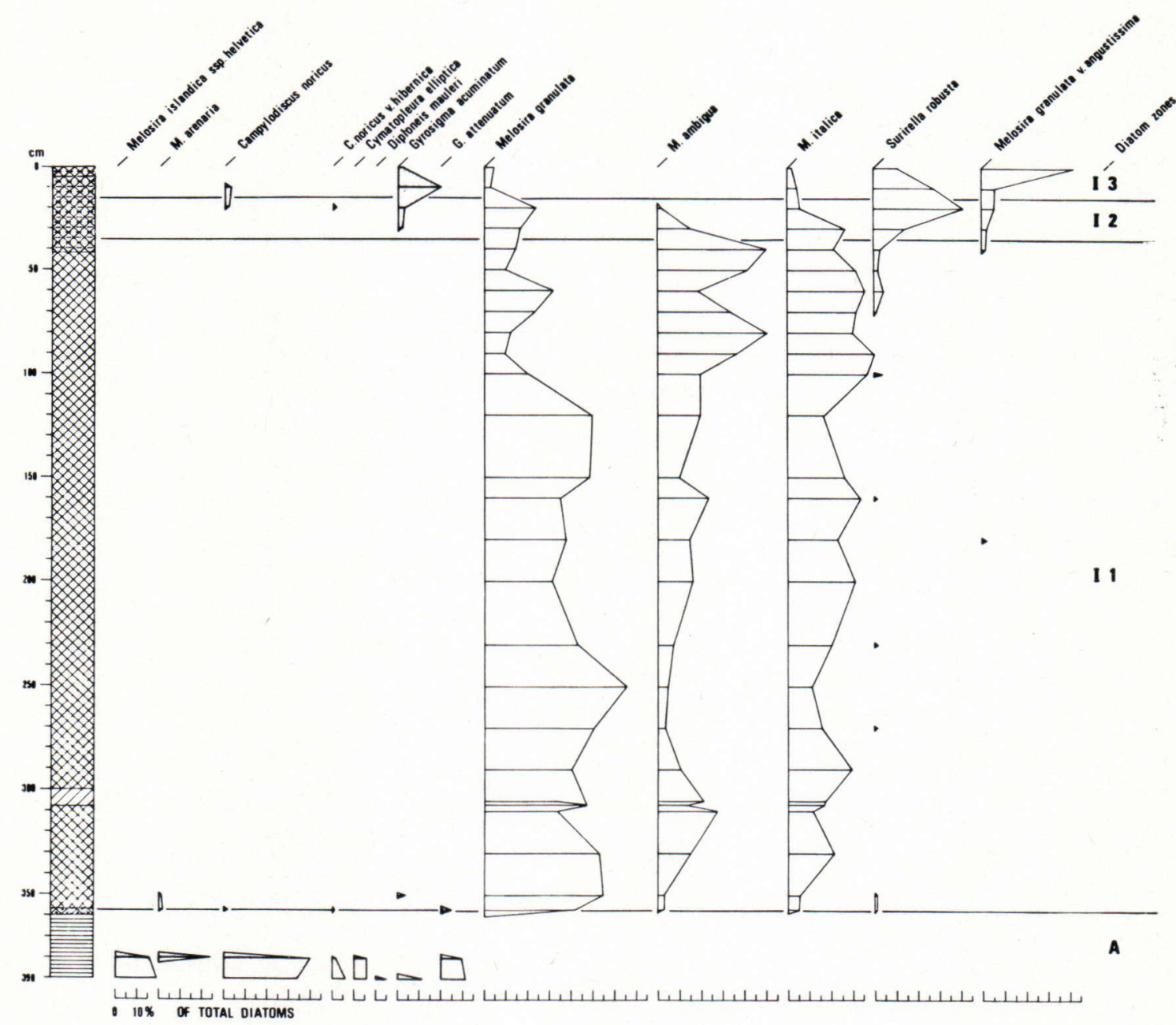

Fig. 6. Percentages of some selected diatom species. For lithostratigraphical symbols see Fig. 3.

\section{Discussion and general conclusions}

As shown earlier, diatom stratigraphy indicates that Iidesjärvi isolated from the Ancylus Lake. In the shoreline displacement of the Baltic Sea in Finland the transition from the Ancylus Lake to the brackishwater stage Mastogloia Sea corresponds to the pollen assemblage zone boundary between the Pine Zone and the Birch-alder-hazel-elm Zone (=V/VI zone boundary according to Sauramo 1958; see also Donner 1951, 1963 and
1971). In the vegetational history of southwestern Finland, the ending of the Ancylus Lake is associated with the general spread of alder (Alnus) This has been dated to about 8000 B.P. (cf. Donner 1971). Although there is good agreement between the dates, the oldest ${ }^{14} \mathrm{C}$ date of $6570 \pm 140$ B.P. is too young for the isolation of Lake Iidesjärvi. Thus a hiatus exists in the lithostratigraphy. Sedimentologically, this gap probably indicates an erosion bottom caused by palaeocurrents in the basin of Iidesjärvi. Hydrological 
conditions later changed during the lake development and organic deposition became possible in this core facies.

As can be seen from Fig. 4, the sedimentation rate of eutrophic Iidesjärvi seems to be more or less constant. The average annual rate of $0.755 \mathrm{~mm}$ is clearly higher than that of the small oligotrophic Lake Vakojärvi, where it is $0.28 \mathrm{~mm} / \mathrm{yr}$ (Donner 1972, p. 8).

The topmost ${ }^{14} \mathrm{C}$ date of $2220 \pm 130$ B.P. in the lithostratigraphy of Iidesjärvi could be somewhat too old, as suggested by closer examination of the regression line in Fig. 4. In any case, the deposition of sulphide-banded clay-gyttja corresponds to the settlement and industrial history of Tampere. Such an error is often attributed to the presence of older allochthonous organic material in the sediments of a lake derived from its catchment area owing to intensive land use (see Huttunen and Tolonen 1977, M. Tolonen 1978 and Vuorela 1980).

The thin pale grey gyttja layer (300$308 \mathrm{~cm}$; see Fig. 3) deserves some comment, for it may indicate transgression of the lake Pyhäjärvi after the formation of the Tammerkoski rapids. Because these two lakes, Pyhäjärvi $(77.0 \mathrm{~m})$ and Iidesjärvi $(77.1 \mathrm{~m})$, are situated at practically the same elevation, the pale grey gyttja layer probably marks the rise of the water level in Lake Iidesjärvi as well. The radiocarbon date of $5390 \pm 140$ B.P. is consistent with the earlier results: viz. that the Tammerkoski rapids were formed in the third millenium B.C. (Virkkala 1949 and 1962).

Some conclusions can be drawn about the vegetational history of the surroundings of the lake. The long-term changes reflected in the pollen diagram of Fig. 5 represent known phases of regional forest history in the area, covering a time span of some 6570 radiocarbon years. The diagram also shows the uppermost part of the Pine Zone corre- sponding to the Late Boreal period when pine was still the predominant species in the forests. It is interesting to note that the ${ }^{14} \mathrm{C}$ dating for the rational limit of Picea $\left(\mathrm{P}^{\circ}\right)$, about 4000 B.P., agrees well with earlier datings in the nearby area (see e.g. Salmi 1962 and Alhonen 1968; see also Donner et al. 1978, Fig. 2). What is more, the ${ }^{14} \mathrm{C}$ date of $2610 \pm 130$ B.P., which refers to the beginning of the Subatlantic period, seems to comply with earlier chronological results (e.g. Alhonen 1968).

As seen in Fig. 5, there is a clear indication of human activity in the catchment area of Lake Iidesjärvi. Although it has not been studied in detail, the first Cerealia-type pollen grain was found in the sediments of the lake at a depth of $60 \mathrm{~cm}$. This may show the beginning of small-scale cultivation, signs of which increase in the upper part of the lithostratigraphy.

Early land use, especially slash-and-burn cultivation, is manifested by the temporary decline of Picea (see Fig. 5) and certain changes in the composition of the NAP flora (see e.g. Vuorela 1976 and Donner et al. 1978). These changes can be detected in many pollen diagrams from south-western, southern and central Finland (Vuorela 1970, 1976, 1978, Huttunen and Tolonen 1977, Donner et al. 1978, Tolonen et al. 1979 and Huttunen 1980).

Note that the uppermost ${ }^{14} \mathrm{C}$ date of $2220 \pm$ 130 B.P. for the beginning of the continuous curve of Cerealia-type pollen is consistent with the radiocarbon dating for the slashand-burn cultivations around Lovojärvi, a lake in the commune of Lammi, where the decline of spruce as a result of forest fires has been dated to $2370 \pm 100$ B.P. in the peat stratigraphy of the Untula bog (Huttunen 1980 , p. 31). Similarly, the earliest pollen stratigraphical evidence of agriculture comes from the Pre-Roman Iron Age (450-350 B.C.) from southwestern and southern Finland 
from the region of Laitila, Karjaa and Espoo (Tolonen et al. 1979) and from near Lahti (Donner et al. 1978, p. 277).

Knowledge of the ecological background of the diatoms makes it possible to interpret the palaeolimnological development of Iidesjärvi. Thus, it is quite clear that this lake has been more or less productive throughout its limnological history. Intensive land use and settlement development increased the eutrophication of Lake Iidesjärvi and finally led to hypolimnetic oxygen deficiency during thermal stratification. This second stage in the eutrophication process (see Alhonen 1979,

\section{References}

Alhonen, P. (1967) Palaeolimnological investigations of three inland lakes in south-western Finland. Acta Bot. Fennica 76, 59 pp.

- (1968) Radiocarbon ages from the bottom deposits of Lake Sarkkilanjärvi, south-western Finland. Bull. Geol. Soc. Finland 40, 65-70.

- (1979) The sedimentary record of the cultural eutrophication and pollution of lakes in Finland. Arch. Hydrobiol. 86: 1, 13-26.

Bradbury, J. P. (1975) Diatom stratigraphy and human settlement in Minnesota. Geol. Soc. America Spec. Paper 171, 74 pp.

- (1978) A palaeolimnological comparison of Burntside and Shagawa lakes, northeastern Minnesota. Ecological Research Series EPA600/3-78-004, 51 pp.

Donner, J. J. (1951) Pollen-analytical studies of lateglacial deposits in Finland. Bull. Comm. géol. Finlande 154, 1-92.

- (1963) The zoning of the Post-glacial pollen diagrams and the main changes in the forest composition. Acta Bot. Fennica 65, 40 pp.

- (1971) Towards a stratigraphical division of the Finnish Quaternary. Comment. Phys.-Math. 41, $281-305$.

- (1972) Pollen frequencies in the Flandrian sediments of Lake Vakojärvi, south Finland. Commentationes Biologicae 53, $19 \mathrm{pp}$.

- , Alhonen, P., Eronen, M., Jungner, H. and Vuorela, I. (1978) Biostratigraphy and radiocarbon dating of the Holocene lake sediments of Työtjärvi and the peats in the adjoining bog Var-
Fig. 5) is characterized in the lithostratigraphy of Lake Iidesjärvi by the formation of sulphide bands in the topmost claygyttja. It has probably been taking place since the beginning of this century, and especially since the 1950s (Toivonen and Ranta 1976).

Acknowledgements - I wish to thank professor Joakim Donner for discussions and fruitful comments, Mr. Högne Jungner for the radiocarbon datings, Mr. Harri Westerling and Mr. Heikki Matiskainen for help in the field work. The author also gratefully acknowledges the financial aid received from the Maj and Tor Nessling Foundation. rassuo west of Lahti in southern Finland. Ann. Bot. Fennici 15, 258-280.

Hustedt, F. (1945) Die Diatomeenflora norddeutscher Seen mit besonderer Berücksichtigung des holsteinischen Seengebietes. Arch. Hydrobiol. 41, 392-414.

Hutchinson, G. E. (1967) A treatise on limnology. Volume II. Introduction to lake biology and the limnoplankton. John Wiley \& Sons, Inc., New York, 1115 pp.

Huttunen, P. (1980) Early land use, especially the slash-and-burn cultivation in the commune of Lammi, southern Finland, interpreted mainly using pollen and charcoal analyses. Acta Bot. Fennica $113,1-45$.

- and Tolonen, K. (1977) Human influence in the history of Lake Lovojärvi, S. Finland. Finskt Museum 1975, 68-105.

Ilmavirta, V. (1980) Phytoplankton in 35 Finnish brownwater lakes of different trophic status. Dev. in Hydrobiol. (in press).

Järnefelt, H. (1952) Plankton als Indikator der Trophiegruppen der Seen. Ann. Acad. Sci. Fennicae A. IV. 18, 27 pp.

- (1956) Zur Limnologie einiger Gewässer Finlands. XVI. Mit besonderer Berücksichtigung des Planktons. Ann. Zool. Soc. „Vanamo» 17: 1, $1-201$.

Jørgensen, E. G. (1948) Diatom communities in some Danish lakes and ponds. Det K. Danske Vidensk. Selsk., Biol. Skr. 5, 140 pp.

Kilham, S. S. and Kilham, P. (1975) Melosira granulata (Ehr.) Ralfs: morphology and ecology 
of a cosmopolitan fresh-water diatom. Verh. Internat. Verein. Limnol. 19, 2716-2721.

Mangerud, J., Andersen, S. T., Berglund, B. E. and Donner, J. J. (1974) Quaternary stratigraphy of Norden, a proposal for terminology and classification. Boreas 3, 109-128.

Matisto, A. (1977) Suomen geologinen kartta $1: 100000$. Kallioperäkartan selitykset, 2123 Tampere. Tampereen kartta-alueen kallioperä (Summary: Precambrian rocks of the Tampere map-sheet area). Geologinen tutkimuslaitos, Espoo, 50 pp.

Mölder, K. and Tynni, R. (1967) Über Finnlands rezente und subfossile Diatomeen I. C. R. de la Soc. géol. Finlande XXXIX, 199-217.

Saarnisto, M. (1971) The history of Finnish lakes and Lake Ladoga. Comment. Phys.-Math. 41, 371-388.

Salmi, M. (1962) Radiocarbon determinations from the bog profile of Lapaneva, Kihniö, western Finland. Bull. Comm. géol. Finlande 204, 195204.

Sauramo, M. (1958) Die Geschichte der Ostsee. Ann. Acad. Sci. Fennicae A. III. 51, 522 pp.

Toivonen, H. (1980) Kapea- ja leveäosmankäämien (Typha angustifolia, T. latifolia) runsaudenmuutoksista 30 vuoden aikana Tampereen seudun pikkujärvissä Abstract: Changes in occurrence of Typha angustifolia and $T$. latifolia during 30 years in small lakes near Tampere, Southern Finland. Memoranda Soc. Fauna Flora Fennica 56, 119-126.

- and Ranta, P. (1976) Tampereen Iidesjärven vesikasvistosta ja sen muutoksista. Abstract: Changes in the aquatic vegetation and flora of the polluted Lake Iidesjärvi, SW Finland. Luonnon Tutkija 80, 129-138.

Tolonen, M. (1978) Palaeoecology of annually laminated sediments in Lake Ahvenainen, S. Finland. III. Human influence in the lake development. Ann. Bot. Fennici 15, 223-240.
Tolonen, K., Tolonen, M., Honkasalo, L., Lehtovaara, A., Sorsa, K. and Sundberg, K. (1976) Esihistoriallisen ja historiallisen maankäytön vaikutuksesta Lammin Lampellonjärven kehitykseen. Abstract: The influence of prehistoric and historic land use on Lake Lampellonjärvi, South Finland. Luonnon Tutkija 80, 1-15.

- Siiriäinen, A. and Hirviluoto, A.-L. (1979) Iron age cultivation in SW Finland. Finskt Museum $1976,5-66$.

Tolvanen, V. (1924) Muinais-Näsijärvi. Terra 36, 208-218.

Tynni, R. (1978) Über Finnlands rezente und subfossile Diatomeen, X. Geological Survey of Finland, Bulletin 296, 55 pp.

- (1980) Über Finnlands rezente und subfossile Diatomeen, XI. Geological Survey of Finland, Bulletin 312, 93 pp.

Virkkala, K. (1949) Ein profil aus dem Grunde des Sees Pyhäjärvi südlich Tampere. C. R. Soc. géol. Finlande 22, 81-85.

- (1962) Suomen geologinen kartta 1:100000, Lehti 2123 Tampere. Maaperäkartan selitys. Summary: Explanation to the map of superficial deposits. Geologinen tutkimuslaitos, $70 \mathrm{pp}$.

Vuorela, I. (1970) The indication of farming in pollen diagrams from southern Finland. Acta Bot. Fennica 87, 40 pp.

- (1976) An instance of slash and burn cultivation in southern Finland investigated by pollen analysis of a mineral soil. Memoranda Soc. Fauna Flora Fennica 52, 29-46.

- (1978) Local settlement history of the Lahti area as shown by pollen analysis. Bull. Geol. Soc. Finland 50, 45-57.

- (1980) Old organic material as a source of dating errors in sediments from Vanajavesi and its manifestation in the pollen stratigraphy. Ann. Bot. Fennici 17, 244-257.

Manuscript received, July 14, 1981. 